\title{
An Experimental on Small Scale Gasoline Engine Performance
}

\author{
Fajri Vidian*, Deli Huda Putra \\ Department of Mechanical Engineering, Universitas Sriwijaya, Indralaya, Sumatera Selatan, Indonesia
}

Received May 6, 2020 ; Revised June 5, 2020; Accepted June 23, 2020

Copyright (@2020 by authors, all rights reserved. Authors agree that this article remains permanently open access under the terms of the Creative Commons Attribution License 4.0 International License

\begin{abstract}
Small-Scale engines are very widely used, especially in developing countries like Indonesia. Its use is intended for various daily activities that require small-scale power. The performance small scale engine is very interesting to investigate for suitable in-field applications. In this study, a small-scale engine was investigated to measure torque $(\mathrm{T})$, brake power $(\mathrm{BP})$, brake mean effective pressure (BMEP) using a rope brake dynamometer with configuration of I. The goal of study is to get an influence of the increase of engine speed on torque, brake power, and BMEP. The experiment was done at engine speed in the range of 1400 to $3500 \mathrm{rpm}$ for each load of 3,4, and $5 \mathrm{~kg}$. The results show an increase in engine speed tends to increase the torque, brake power, and BMEP generated for each load used. The maximum of torque, brake power, and BMEP were $4.53 \mathrm{Nm}, 1.67 \mathrm{~kW}$, and $349 \mathrm{kPa}$ respectively at $3521 \mathrm{rpm}$ and the load of $5 \mathrm{~kg}$. The result of brake power of the experiment was compared to report at the literature with differences about $2.3 \%$. The value of BMEP was in the range of standard for small scale engines. This result has given a contribution combined influence of speed and load on the T, BP, and BMEP.
\end{abstract}

Keywords Small Scale, Engine, Torque, Brake Power, BMEP, Gasoline

\section{Introduction}

The use of a small gasoline scale engine is very popular nowadays especially in Indonesia, for use in various field applications such as pump drive, electricity generator, grain crusher, coconut husk peeler, chicken feather release, propeller or boat drive, and others. According to [1] small scale engine has power below $10.4 \mathrm{~kW}$. Correlation of speed and load on torque (T), brake power (BP), and brake mean effective pressure (BMEP) that can be produced by small scale engine is interesting to investigate. Many types of equipment could be utilized to identify the value of torque and brake power on the engine which is one of it is rope brake dynamometer [2]. Until now, many researchers have used rope brake dynamometer to present the value of the $\mathrm{T}$ and $\mathrm{BP}$ on small scale engines [3]. It is caused by the easy design and fabricated.

Several researchers have investigated the torque, brake power and BMEP on the gasoline engine. Kahraman et al., [4] studied a comparison the influence of speed against the T, BP, and BMEP for pure gasoline fuel about $35 \mathrm{Nm}, 8$ $\mathrm{kW}$, and $350 \mathrm{kPa}$ respectively. Yusaf et al, [5] investigated the influence of against the $\mathrm{T}$ and $\mathrm{BP}$ using gasoline and blended fuel of gasoline-ethanol, the results showed the maximum of the $\mathrm{T}$ and $\mathrm{BP}$ of $101 \mathrm{Nm}$ and $45 \mathrm{~kW}$ respectively for pure gasoline as fuel. Arpa et al, [6] explored a comparison the influence of speed against the $T$, $\mathrm{BP}$, and BMEP using pure gasoline and gasoline-like fuel, the results showed the maximum of the $\mathrm{T}, \mathrm{BP}$, and BMEP for pure gasoline as fuel about $94 \mathrm{Nm}, 33 \mathrm{~kW}$, and $900 \mathrm{kPa}$.

Ebrahimi et al, [7] studied comparison of the influence of speed against the $\mathrm{T}$ using gasoline and natural gas as fuel, the results showed the maximum of the T about $104 \mathrm{Nm}$ for gasoline at $\varnothing=1$. Hamada et al, [8] reported the influence of speed against the T, BP, and BMEP on a small motorcycle engine, the result showed the maximum of the $\mathrm{T}$, BP, and BMEP of $36.2 \mathrm{Nm}, 10.84 \mathrm{~kW}$ and $454 \mathrm{kPa}$ respectively. Lawal et al, [9] experimented with the influence of speed against the $\mathrm{T}$ and $\mathrm{BP}$, the results showed the maximum of the T and $\mathrm{BP}$ of $81 \mathrm{Nm}$ and $33.38 \mathrm{~kW}$ for gasoline RON 91 as fuel. Karagoz et al, [10] investigated the influence of speed against the BP using pure gasoline and gasoline mixture with hydrogen and water injection, the results showed the maximum the BP about $25 \mathrm{~kW}$ for pure gasoline as fuel. Cahyono et al, [11] reported the influence of speed against the BP on a gasoline engine, the results showed the maximum of the BP about $55 \mathrm{~kW}$ on pure gasoline as fuel. Omojola et al, [12] studied a comparison the influence of speed against the T, BP, and BMEP using pure gasoline and gasoline-biogas blended as 
fuel, the result showed the maximum of the $\mathrm{T}, \mathrm{BP}$, and BMEP were $8.5 \mathrm{Nm}, 311 \mathrm{~kW}, 0.00023 \mathrm{~N} / \mathrm{m}^{2}$ respectively. Sertkaya et al,[13] investigated a comparison of the influence of speed against the T and BP using pure gasoline and mixture gasoline with boron as fuel, the results showed the maximum of the $\mathrm{T}$ and $\mathrm{BP}$ of pure gasoline engine were about $26 \mathrm{Nm}$ and $16 \mathrm{~kW}$ respectively. Nayak et al, [14] experimented with a comparison of the influence of speed against the BP using dual fuel mode LPG-gasoline and pure gasoline, the results showed the maximum of the BP about $33 \mathrm{~kW}$ for pure gasoline as fuel.

Rashid et al, [15] studied the influence of speed against the $\mathrm{T}$ and BP using gasoline RON 95,97 and 105. The result showed the maximum the $\mathrm{T}$ and $\mathrm{BP}$ of about $51 \mathrm{Nm}$ and $5.1 \mathrm{~kW}$ for RON 105. Nasir, [16] investigated a comparison to the influence of speed against the BP using mixture ethanol-gasoline and pure gasoline as fuel, the results showed the maximum the $\mathrm{BP}$ of $1.2 \mathrm{~kW}$ for pure gasoline. Al-Gburi, [17] experimented to get a comparison the influence of speed against the BP using mixture ethanol- gasoline and pure gasoline as fuel, the results showed the maximum of the BP for pure gasoline could get about $0.95 \mathrm{~kW}$. S. Allam et al, [18] investigated the gasoline engine using compressed air to get the influence of speed against the BP, the results showed the maximum the BP of $3.2 \mathrm{~kW}$ at operation normal condition. Charan et al, [19] reported a comparison of the influence of engine load to the BP on a small-scale gasoline engine with turbocharger and the results to show the maximum of the BP without turbocharged was $1.653 \mathrm{~kW}$.

According to the results reported by the researcher before, we could get a conclusion. The first is the results of the experiment for the influence of speed against the brake power (BP) at low power (below $3.6 \mathrm{~kW}$ ) are still rare and the second is the influence of engine load to the brake power (BP) is still rare. This study was developed a small-scale gasoline engine integrated with rope brake dynamometer configuration of I. This study aimed to study an influence of the speed and load on torque, brake power, and BMEP. The uniqueness of this experiment is to present the combined influence of speed and load on torque, brake power, and BMEP.

\section{Methodology}

The experiments carried out using a small-scale engine that is widely sold in the market in Indonesia with specifications listed in Table 1 . The rope brake dynamometer used is configuration of I which was developed at the energy conversion laboratory, department of mechanical engineering, Universitas Sriwijaya. The arrangement of experimental equipment is shown in Figure 1 . The engine speed was measured utilizing a tachometer. The experiment was carried out at a constant load with engine speed varied. The three loads used were 3, 4 and 5 $\mathrm{kg}$. The engine speed was regulated in a range of 1500 to $3500 \mathrm{rpm}$. The equation of 1-3 was used to calculation the $\mathrm{T}$, BP and BMEP where $\mathrm{W}$ is dead weight in $(\mathrm{N}), \mathrm{S}$ is Spring balanced reading in $(\mathrm{N}), \mathrm{r}_{\mathrm{t}}$ is the distance from the center of the drum in (m), N is engine rotation in (rpm), $n_{r}$ is one complete cycle with its the number of crank revolutions, which is 2 for a four-stroke, $\mathrm{V}_{\mathrm{d}}$ is displacement volume $[3,6]$.

$$
\begin{gathered}
\mathrm{T}=(\mathrm{W}-\mathrm{S}) \cdot \mathrm{r}_{\mathrm{t}}(\mathrm{Nm}) \\
\mathrm{BP}=2 \pi \mathrm{NT} / 60000(\mathrm{~kW}) \\
\mathrm{BMEP}=\mathrm{BP} \cdot \mathrm{n}_{\mathrm{r}} \cdot 60 / \mathrm{V}_{\mathrm{d}} \cdot \mathrm{N}(\mathrm{kPa})
\end{gathered}
$$$$
\text { Table 1. Engine specification }
$$

\begin{tabular}{ccc}
\hline No & Parameter & Value \\
\hline 1 & Maximum Power & $3.6 \mathrm{~kW}$ \\
2 & Speed & $3600 \mathrm{rpm}$ \\
3 & Bore & $6.8 \mathrm{~cm}$ \\
4 & Stroke & $4.5 \mathrm{~cm}$ \\
5 & Capacity & $163 \mathrm{cc}$ \\
6 & Number of Cylinder & 1 \\
7 & Type of Engine & 4 strokes \\
8 & Ratio of Compression & $8.5: 1$ \\
9 & Fuel & Gasoline \\
\hline
\end{tabular}

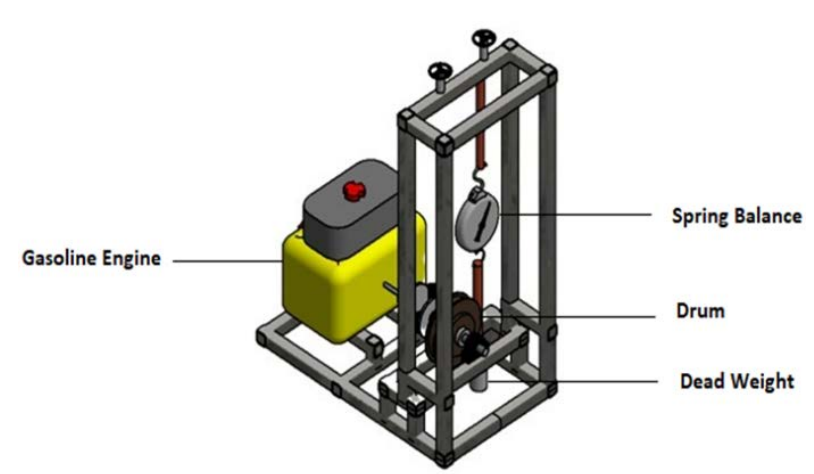

Figure 1. The experimental set-up

\section{Results and Discussion}

\subsection{The Comparison of the Measurement}

Figure 2 shows the BP comparison of the experiment and the results reported by [19]. These results were very comparable to the reported by [19] at the same configuration of rope brake dynamometer and engine specification at the average of differences about $2.3 \%$. The comparison is very important for proof the accuracy of the experimental set before continue to measure the influence of speed against the T, BP, and BMEP at the difference of load. 


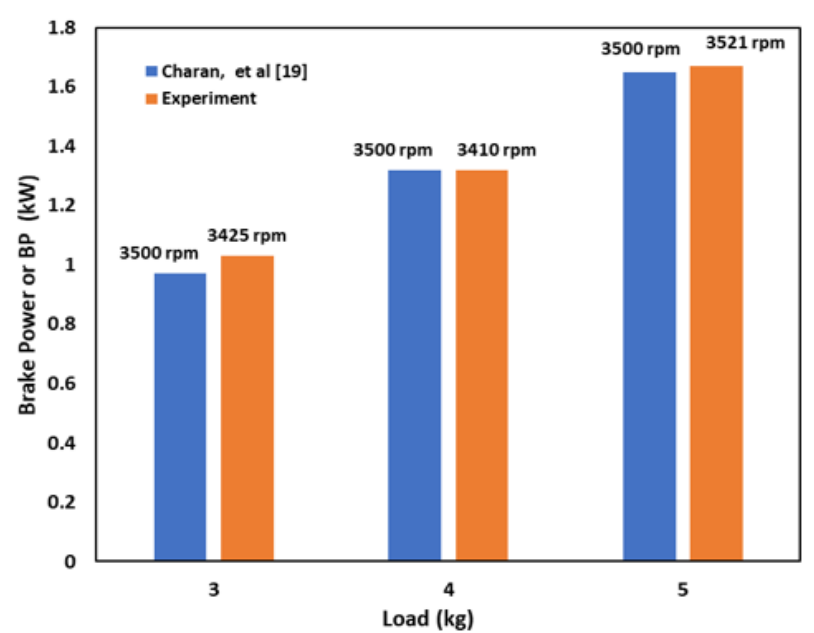

Figure 2. The comparison between the results of experiment and charan et al [19]

\subsection{The Influence of Engine Speed on Torque (T)}

Figure 3 shows the influence speed on torque, the increase in speed from about 1400 to $3500 \mathrm{rpm}$ at every load of 3,4,5 kg would increase the torque. This caused by the increasing tangential force produced by engine and friction power of the engine (mechanical loss) still did not dominant. These results have the same trend as reported by [12]. From this result, it could be explained that the increasing load at the speed nearly constant would increase the torque too. The minimum torque of $1.85 \mathrm{Nm}$ is at speed of $1400 \mathrm{rpm}$ and the load of $3 \mathrm{~kg}$. The maximum torque of $4.53 \mathrm{Nm}$ is at speed of $3521 \mathrm{rpm}$ and the load of $5 \mathrm{~kg}$.

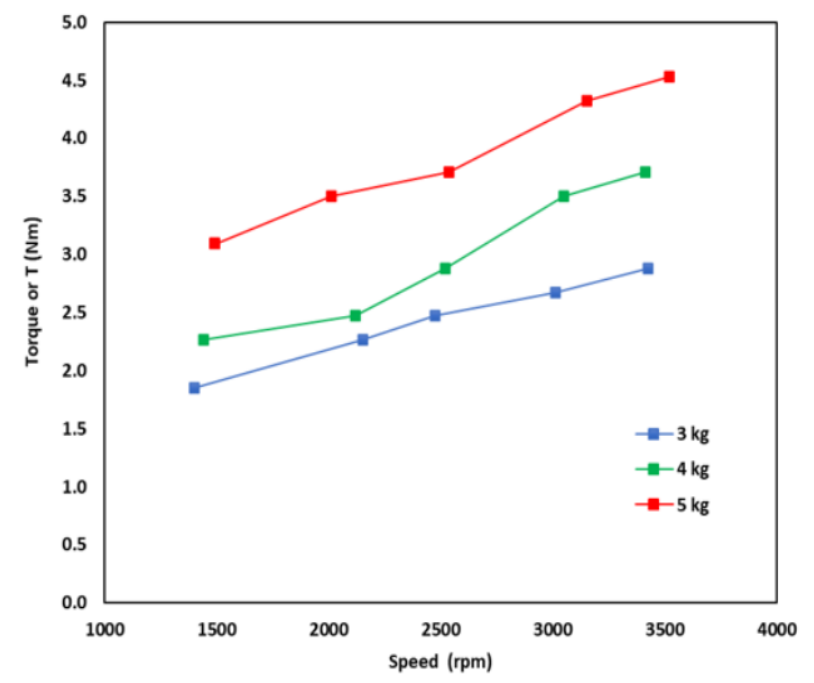

Figure 3. Engine speed versus torque (T)

\subsection{The Influence of Engine Speed on Brake Power (BP)}

Figure 4 shows the influence speed on brake power, the brake power increased with increasing speed from about 1400 to $3500 \mathrm{rpm}$ at every load of 3,4,5 kg. This is because an increase in speed at a constant load will increase torque as shown in Figure 3, where the friction power is more less than the useful work. These results have the same trend as the results were obtained by [5-6, 12,14]. From this figure, we could conclude the increasing load at nearly constant speed would increase the brake power too. This result has the same trends as the result obtained by [19]. The minimum of brake power was yang $0.27 \mathrm{~kW}$ at speed $1400 \mathrm{rpm}$ and the load of $3 \mathrm{~kg}$. The Maximum of brake power was $1.67 \mathrm{~kW}$ at speed of 3521 rpm and load of $5 \mathrm{~kg}$.

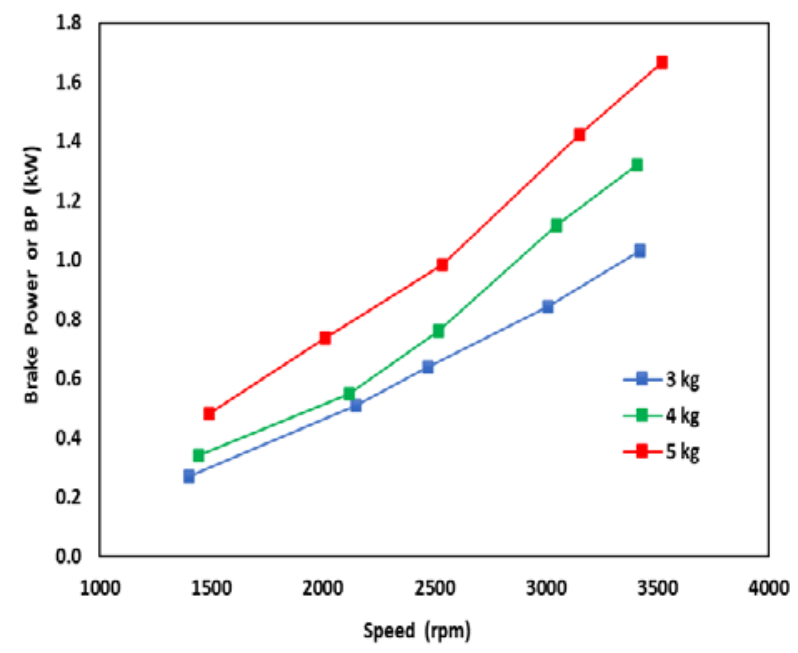

Figure 4. Engine speed versus brake power (BP)

\subsection{The Influence of Engine Speed on Brake Mean Effective Pressure (BMEP)}

Figure 5 shows the influence speed on BMEP, and an increasing speed will increase BMEP. This caused by an influence of brake power increased as shown in figure 4 . The minimum BMEP was $142 \mathrm{kPa}$ on engine speed of $1400 \mathrm{rpm}$ and the load of $3 \mathrm{~kg}$. The maximum BMEP was $349 \mathrm{kPa}$ at a speed of $3521 \mathrm{rpm}$ and a load of $5 \mathrm{~kg}$. This result has the same graph's trend on the report by [12] and has the same range value between 100 to $350 \mathrm{kPa}$ that reported by [4]. This result has a value near the same as reported by [8]. According to [20] the value of BMEP for small scale engines is about $400 \mathrm{kPa}$ at engine speed of $4500 \mathrm{rpm}$. 


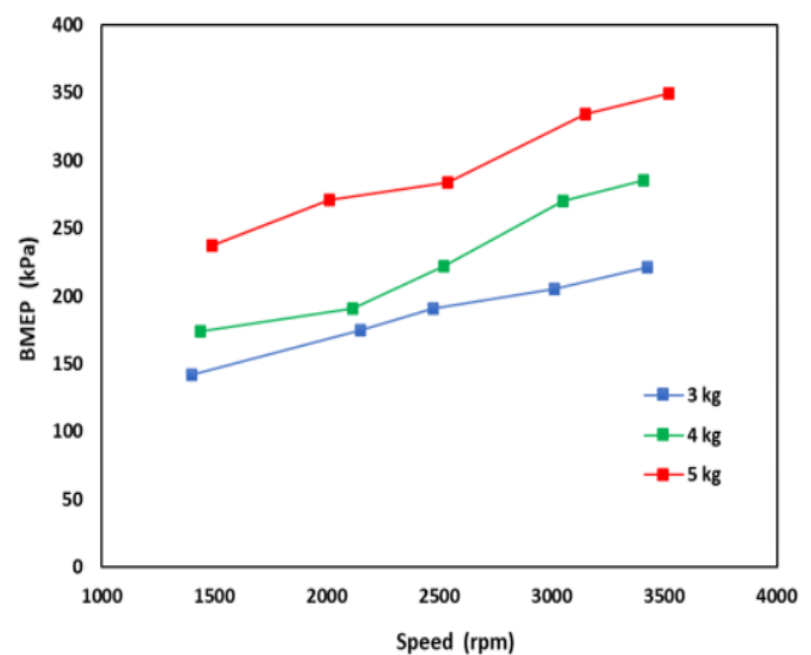

Figure 5. Engine speed versus brake mean effective pressure (BMEP)

\section{Conclusions}

A small-scale gasoline engine with a maximum power of $3.6 \mathrm{~kW}$ has been integrated with the rope brake dynamometer with configuration of I to measure the T, BP, and BMEP. The test results show an increase in engine speed between 1400 to $3500 \mathrm{rpm}$ for each loading of 3.4.5 $\mathrm{kg}$ will increase the resulting the T, BP, and BMEP. The minimum the T, BP, and BMEP were $1.85 \mathrm{Nm}, 0.27 \mathrm{~kW}$, and $142 \mathrm{kPa}$ respectively at $1400 \mathrm{rpm}$ and $3 \mathrm{~kg}$ load. The maximum of the T, BP, and BMEP were $4.53 \mathrm{Nm}, 1.67$ $\mathrm{kW}$, and $349 \mathrm{kPa}$ respectively at $3521 \mathrm{rpm}$ and the load of $5 \mathrm{~kg}$.

\section{REFERENCES}

[1] Homdoung N, Tippayawong N, Dussadee N, Performance investigation of a modified small engine fueled with producer gas, Maejo International Journal of Science and Technology, 9, 01, 10-20, 2015.

[2] Gopinath R, Design of a rope brake dynamometer, Middle-East Journal of Scientific Research, 20, 5, 650-655, 2014.

[3] Vidian F, Putra DH, Kholis A, A short review and development of rope brake dynamometer for measurement of brake power on small scale engine, Journal of Mechanical Engineering Research and Developments, 43, 2, 144-153, 2020.

[4] Kahraman E, Ozcanlı SC, Ozerdem B, An experimental study on performance and emission characteristics of a hydrogen fuelled spark ignition engine, International Journal of Hydrogen Energy, 32, 2066-2072, 2007.

[5] Yusaf T, Buttsworth D, Najafi G, Theoretical and experimental investigation of SI engine performance and exhaust emissions using ethanol-gasoline blended fuels,
Proceedings of ICEE 2009 3rd International Conference on Energy and Environment, 7-8 December 2009, Malacca, Malaysia, 195-201, 2009.

[6] Arpa O, Yumrutas R, Experimental investigation of gasoline-like fuel obtained from waste lubrication oil on engine performance and exhaust emission, Fuel Processing Technology, 91, 197-204, 2010.

[7] Ebrahimi R, Mercier M, Experimental study of performance of spark ignition engine with gasoline and natural gas, IJE Transactions B: Applications, 24, 1, 65-74, 2011.

[8] Hamada KI, Rahman MM, An experimental study for performance and emissions of a small four stroke SI engine for modern motor cycle. International Journal of Automotive and Mechanical Engineering (IJAME), 10, 1852-1865, 2014.

[9] Lawal DU, Imteyaz BA, Abdelkarim AM, Khalifa AE, Performance of spark ignition engine using gasoline-91 and gasoline-95, International Journal of Innovative Science, Engineering \& Technology, 1, 6, 464-469, 2014.

[10] Karagoz Y, Yuksek L, Sandalci T, Dalkilic AS, An experimental investigation on the performance characteristics a hydrogen enriched gasoline engine with water injection, International Journal Hydrogen Energy, 40, 692-705, 2015.

[11] Cahyono B, Nugroho TF, Bakar RA, Experiment analysis an effect ethanol/gasoline blend at port injection gasoline engine, Asian Journal of Applied Sciences, 3, 3, 506-512, 2015.

[12] Omojola A, Adeyemo, Babatunde S, Development and testing of biogas-petrol blend as an alternative fuel for spark ignition engine, International Journal of Scientific \& Technology Research, 4, 09, 179 - 186, 2015.

[13] Sertkaya AA, Akikbiyik T, Operate with a gasoline internal combustion engine evaluation of different boron addition of the fuel additive inside performance and emissions impact, Journal of Polytechnic, 19, 4, 633-640, 2016.

[14] Nayak V, Shankar KS, Dinesha P, Mohanan P, An experimental investigation on performance and emission parameters of a multi-cylinder SI engine with gasolineLPG dual fuel mode of operation, Biofuels, 1-11, 2016.

[15] Rashid AK, Mansor MRA, Ghopa WAW, Harun Z, Mahmood WMFW, An experimental study of the performance and emissions of spark ignition gasoline engine, International Journal of Automotive and Mechanical Engineering (IJAME), 13, 3, 3540-3554, 2016.

[16] Nasir KF, Experimental investigation of using ethanol-gasoline in spark ignition engine, Al-Nahrain Journal for Engineering Sciences (NJES), 21, 3, 368-373, 2018.

[17] Al-Gburi H, Experimental investigation of using ethanol-gasoline 750 on the performance and exhaust emmision of spark ignition engine in iraq, Journal of University of Babylon for Engineering Sciences, 26, 8, 242-255, 2018.

[18] Allam S, Zakaria M, Experimental investigation of 
compressed air engine performance, International Journal of Engineering Inventions, 7, 1(II), 13-20, 2018.

[19] Charan MS, Kadekar SM, Pramodh B R, Phanikrishna G V, Aparna. B, Perforance anmalysis of turbocharged four stroke single cylinder spark ignition engine, International Journal of Innovative Research in Advanced Engineering
(IJIRAE), 6, 6, 108-113, 2019.

[20] Heywood JB. Internal combustion engine fundamentals. New York: McgrawHill; 1988. 